\title{
Renovação de Pastagem Degradada de Capim-Gordura com a Introdução de Forrageiras Tropicais Adubadas com Nitrogênio ou em Consórcios ${ }^{1}$
}

\section{Luciano de Melo Moreira², Dilermando Miranda da Fonseca ${ }^{3}$, Cláudio Manoel Teixeira Vítor ${ }^{2}$, Anderson Jorge de Assis ${ }^{2}$, Domicio do Nascimento Júnior ${ }^{3}$, José Ivo Ribeiro Júnior ${ }^{4}$, José Antônio Obeid ${ }^{3}$}

\begin{abstract}
RESUMO - Um experimento foi conduzido com objetivo de avaliar a produtividade e qualidade do capim-braquiária (Brachiaria decumbens Stapf. cv. Basilisk) e do capim-jaraguá (Hyparrhenia rufa (Ness) Stapf.) adubados com nitrogênio (N) ou em consórcios com estilosantes (Stylosanthes guianensis (Aubl.) Swartz cv. Mineirão), introduzidos em uma pastagem degradada. Foram avaliadas duas gramíneas (capim-braquiária e capim-jaraguá), quatro doses de $\mathrm{N}(0,50,100$ e $150 \mathrm{~kg} / \mathrm{ha}$ ) e dois tratamentos referentes aos consórcios capim-braquiária + estilosantes e capim-jaraguá + estilosantes. Após estabelecimento das forrageiras, foram realizadas duas avaliações (colheitas). As produções de matéria seca (MS) do capim-braquiária aumentaram de 1.824 para $4.604 \mathrm{~kg} / \mathrm{ha}$ e de 1.019 para 2.149 $\mathrm{kg} / \mathrm{ha}$ nas duas colheitas, respectivamente, quando as doses de $\mathrm{N}$ extremas foram comparadas, porém não houve resposta do capimjaraguá. O teor de proteína bruta (PB) do capim-braquiária elevou de 3,18 para 5,68 dag $/ \mathrm{kg}$ apenas na primeira colheita, enquanto o capim-jaraguá apresentou incremento de 2,53 para 3,72 dag/kg e de 7,32 para 8,45 dag/kg, respectivamente, em ambas as colheitas, quando comparadas às doses extremas. Os teores de fibra em detergente neutro (FDN) e fibra em detergente ácido das gramíneas não foram influenciados pela aplicação de N. Em ambas as colheitas, ao se elevarem as doses de N, houve diminuição dos teores de P nas duas gramíneas e de $\mathrm{K}$ no capim-braquiária. Os teores de Ca e Mg das gramíneas, em sua maioria, não foram influenciados pelo $\mathrm{N}$, em ambas as colheitas. As produções médias de MS dos dois consórcios foram superiores às produções médias das duas gramíneas adubadas, com incrementos de 42,62 e 15,00\% no rendimento forrageiro, na primeira e segunda colheitas, respectivamente. As forrageiras em consórcios, de forma geral, apresentaram teores de PB e Ca mais elevados e de FDN mais baixos que as gramíneas puras adubadas com $\mathrm{N}$, melhorando a qualidade do pasto.
\end{abstract}

Palavras-chave: adubação, Brachiaria decumbens, Hyparrhenia rufa, minerais, proteína bruta, Stylosanthes guianensis

\section{Renewing the Degraded Melinis minutiflora Pasture by Introduction of Tropical Forages Fertilized with Nitrogen or under Mixture Cropping System}

ABSTRACT - This study was carried out to evaluate the productivity and quality of either Brachiaria decumbens Stapf. cv. Basilisk and Hyparrhenia rufa (Ness) Stapf. grasses fertilized with nitrogen (N) or mixed with stylosanthes (Stylosanthes guianensis (Aubl.) Swartz cv. Mineirão), introduced into a degraded pasture. Both grasses were evaluated, as well as four doses of nitrogen $(0,50,100$ and $150 \mathrm{~kg} / \mathrm{ha}$ ) and two treatments that consisted of mixing B. decumbens and S. guianensis as well as H. rufa and S. guianensis. After forages were established, two evaluations were also performed (harvests). The dry matter (DM) yields of $B$. decumbens increased from 1,824 up to $4,604 \mathrm{~kg} / \mathrm{ha}$ and from 1,019 to $2,149 \mathrm{~kg} / \mathrm{ha}$ in both respective harvests, when the extreme $\mathrm{N}$ doses were compared, but $H$. rufa showed no response. The crude protein $(\mathrm{CP})$ content in $B$. decumbens increased from 3.18 up to $5.68 \mathrm{dag} / \mathrm{kg}$ at the first harvest only, whereas H. rufa showed an increment from 2.53 to $3.72 \mathrm{dag} / \mathrm{kg}$ and from 7.32 to $8.45 \mathrm{dag} / \mathrm{kg}$ in both respective harvests, compared to the extreme doses. The contents of both neutral detergent fiber (NDF) and acid detergent fiber in the grasses were not affected by $\mathrm{N}$ application. When $\mathrm{N}$ doses increased, the $\mathrm{P}$ contents in both grasses and $\mathrm{K}$ contents in $\mathrm{B}$. decumbens were reduced at both harvests. Most contents of $\mathrm{Ca}$ and $\mathrm{Mg}$ in grasses were not affected by $\mathrm{N}$ at both harvests. The average DM yields of both mixtures were superior to the average yields of both fertilized grasses, as showing increments of $42.62 \%$ and $15.00 \%$ in forage yield at the first and second harvests, respectively. In general, the mixed forages showed higher contents of $\mathrm{CP}$ and $\mathrm{Ca}$, but lower NDF values than those N-fertilized pure grasses, therefore improving the quality of the pasture.

Key Words: fertilization, Brachiaria decumbens, Hyparrhenia rufa, minerals, crude protein, Stylosanthes guianensis

\footnotetext{
${ }^{1}$ Parte da dissertação apresentada à UFV pelo primeiro autor como parte das exigências para obtenção do título Magister Scientiae

2 Zootecnista, Estudante de Doutorado, Departamento de Zootecnia - UFV. Viçosa, MG. CEP: 36570-000. Endereço eletrônico: ds30062@vicosa.ufv.br

3 Professor do Departamento de Zootecnia da UFV - Viçosa, MG. Endereço eletrônico: dfonseca@ufv.br

${ }^{4}$ Professor do Departamento de Informática da UFV - Viçosa, MG.
} 


\section{Introdução}

A Zona da Mata de Minas Gerais é caracterizada por áreas de relevo acidentado, solos ácidos e de baixa fertilidade. Segundo Lombardi Neto (1993), as pastagens naturalizadas estão localizadas nessas áreas marginais, em razão do próprio planejamento das propriedades agrícolas, posto que as áreas nobres são ocupadas por lavouras, mais exigentes em fertilidade do solo e mais rentáveis que a pecuária.

O capim-gordura (Melinis minutiflora Beauv.) é uma forrageira naturalizada quee predominou na Zona da Mata Mineira até a década de 80, mas, embora adaptada, apresenta baixo rendimento, suportando sob lotação contínua, aproximadamente, apenas 0,4 UA/ha.ano, em regime extrativista de produção animal (Brockington et al., 1986).

$\mathrm{O}$ inadequado manejo aplicado às pastagens ao longo dos anos, sobretudo a queima indiscriminada e o superpastejo, contribuíram para a baixa produtividade e qualidade das forrageiras nessa região. Isso tem proporcionado perdas da camada superficial do solo e permitido a invasão e dominância de espécies sem interesse forrageiro, ocasionando um processo dinâmico de degradação das pastagens (Cóser \& Cruz Filho, 1989).

O nitrogênio $(\mathrm{N})$ é um dos principais nutrientes para a intensificação da produtividade das gramíneas forrageiras, pois é o constituinte essencial das proteínas e interfere diretamente no processo fotossintético, por meio de sua participação na molécula de clorofila. Portanto, se não for disponibilizado freqüentemente, acarreta redução na produção do pasto, iniciando o processo de degradação (Meirelles, 1993).

O potencial produtivo das forrageiras na pastagem pode ser melhorado com a aplicação de fertilizantes, notadamente os nitrogenados (Carvalho \& Saraiva, 1987). Porém, sua utilização tem sido limitada pelo custo, em virtude da extensão das áreas envolvidas e da necessidade de aplicações freqüentes (Döbereiner, 1997). Assim, outra alternativa é a introdução de leguminosas adaptadas às condições edafoclimáticas da região, a fim de aumentar a quantidade e qualidade da forragem disponível nessas áreas (Cóser \& Cruz Filho, 1989). A fixação biológica de $\mathrm{N}$ atmosférico $\left(\mathrm{N}_{2}\right)$ pelas bactérias dos gêneros Rhizobium e Bradyrhizobium, em simbiose com leguminosas forrageiras, como o Stylosanthes guianensis (Aubl.) Swartz vr. Vulgaris cv. Mineirão (estilosantes), fornece condições a esta de atender sua exigência e a da gramínea consorciada, constituindo meio econômico para aumentar a qualidade e produtividade dos pastos (Cantarutti \& Boddey, 1997).

O capim-braquiária (Brachiaria decumbens Stapf.) e o capim-jaraguá (Hyparrhenia rufa (Ness) Stapf.) são morfofisiologicamente diferentes quanto a hábito de crescimento, dinâmica de perfilhamento e de rebrotação, altura de meristema apical e época e freqüência de florescimento, entre outros fatores (Pupo, 1979; Soares Filho, 1994). No entanto, são comprovadamente bem adaptadas (Carvalho \& Cruz Filho, 2000) às condições edafoclimáticas a que são submetidas na Zona da Mata de Minas, podendo responder melhor à adubação nitrogenada, ou serem utilizadas em consórcio com leguminosa fixadora de $\mathrm{N}$, e, portanto, substituirem o capim-gordura nessas pastagens naturalizadas como alternativa para viabilizar a solução para o problema de sua degradação. Portanto, pode-se elevar a produtividade e o valor nutritivo do pasto, permitir a sustentabilidade do sistema e tornar a produção animal racional e economicamente viável para a região.

Conduziu-se este estudo com o objetivo de avaliar a produtividade e a composição químico-bromatológica do capim-braquiária e do capim-jaraguá adubados com $\mathrm{N}$ ou em consórcios com estilosantes, introduzidos em pastagem degradada de capim-gordura.

\section{Material e Métodos}

O estudo foi conduzido em área declivosa de pastagem naturalizada de capim-gordura degradada, pertencente ao Departamento de Zootecnia da Universidade Federal de Viçosa (UFV), Viçosa (MG), no período de outubro de 1998 a dezembro de 1999. Viçosa está localizada na Zona da Mata, em uma altitude de $651 \mathrm{~m}, 20^{\circ} 45^{\prime}$ de latitude sul e $42^{\circ} 51^{\prime}$ de longitude oeste. Apresenta temperatura média anual de $19^{\circ} \mathrm{C}$, com média das máximas e mínimas de $22,1^{\circ} \mathrm{C}$ e $15^{\circ} \mathrm{C}$, respectivamente. A umidade relativa do ar é, em média, de $80 \%$ e a precipitação média anual, de $1.340 \mathrm{~mm}$, com estações seca e chuvosa bem definidas (Estação Meteorológica da UFV). Os dados referentes ao período experiemental encontram-se na Tabela 1. Seu clima, pelo sistema de Köppen (1948), é classificado como Cwa, subtropical, com inverno ameno e seco.

O experimento consistiu de um fatorial $(2 \times 4)+2$, que correspondeu, respectivamente, a duas espécies, Brachiaria decumbens (capim-braquiária) e

R. Bras. Zootec., v.34, n.2, p.442-453, 2005 
Tabela 1 - Precipitação pluvial mensal e temperaturas médias em Viçosa, no período de outubro/98 a dezembro/99

Table 1 - Monthly rainfall and average temperatures in Viçosa county from October/98 to Dezembro/99

\begin{tabular}{|c|c|c|c|}
\hline \multirow[b]{2}{*}{$\begin{array}{l}\text { Período (mês) } \\
\text { Period (month) }\end{array}$} & \multirow{2}{*}{$\begin{array}{c}\text { Precipitação } \\
\text { Rainfall } \\
\text { (mm) }\end{array}$} & \multicolumn{2}{|c|}{$\begin{array}{c}\text { Temperatura }\left({ }^{\circ} \mathrm{C}\right) \\
\text { Temperature }\end{array}$} \\
\hline & & $\begin{array}{l}\text { Máximas } \\
\text { Maximum }\end{array}$ & $\begin{array}{l}\text { Mínimas } \\
\text { Minimum }\end{array}$ \\
\hline $\begin{array}{l}\text { Outubro } \\
\text { October }\end{array}$ & 257,5 & 25,6 & 16,6 \\
\hline $\begin{array}{l}\text { Novembro } \\
\text { November }\end{array}$ & 216,9 & 26,0 & 16,9 \\
\hline $\begin{array}{l}\text { Dezembro } \\
\text { December }\end{array}$ & 105,3 & 28,8 & 18,2 \\
\hline $\begin{array}{l}\text { Janeiro } \\
\text { January }\end{array}$ & 154,2 & 30,3 & 18,9 \\
\hline $\begin{array}{l}\text { Fevereiro } \\
\text { February }\end{array}$ & 95,0 & 30,2 & 18,5 \\
\hline $\begin{array}{l}\text { Março } \\
\text { March }\end{array}$ & 273,7 & 28,5 & 17,8 \\
\hline $\begin{array}{l}\text { Abril } \\
\text { April }\end{array}$ & 36,5 & 27,7 & 16,1 \\
\hline $\begin{array}{l}\text { Maio } \\
\text { May }\end{array}$ & 2,0 & 25,3 & 11,6 \\
\hline $\begin{array}{l}\text { Junho } \\
\text { June }\end{array}$ & 13,2 & 24,5 & 11,5 \\
\hline $\begin{array}{l}\text { Julho } \\
\text { July }\end{array}$ & 4,2 & 24,3 & 12,4 \\
\hline $\begin{array}{l}\text { Agosto } \\
\text { August }\end{array}$ & 0,0 & 25,9 & 08,9 \\
\hline $\begin{array}{l}\text { Setembro } \\
\text { September }\end{array}$ & 46,7 & 27,0 & 12,7 \\
\hline $\begin{array}{l}\text { Outubro } \\
\text { October }\end{array}$ & 40,0 & 25,0 & 14,7 \\
\hline $\begin{array}{l}\text { Novembro } \\
\text { November }\end{array}$ & 69,3 & 25,5 & 16,1 \\
\hline $\begin{array}{l}\text { Dezembro } \\
\text { December }\end{array}$ & 108,5 & 27,7 & 18,7 \\
\hline
\end{tabular}

Estação meteorológica da UFV.

UFV meteorological station.

Hyparrhenia rufa (capim-jaraguá), quatro doses de nitrogênio $(\mathrm{N})(0,50,100$ e $150 \mathrm{~kg} / \mathrm{ha})$ e dois tratamentos adicionais referentes aos dois consórcios, B. decumbens + Stylosanthes guianensis cv. Mineirão (estilosantes) e H. rufa + S. guianensis cv. Mineirão, em blocos ao acaso com três repetições. Os dez tratamentos foram: capim-braquiária (B) sem adubação nitrogenada $(\mathrm{B}+0 \mathrm{~N})$, com $50 \mathrm{~kg} / \mathrm{ha}$ de $\mathrm{N}$ $(\mathrm{B}+50 \mathrm{~N})$, com $100 \mathrm{~kg} / \mathrm{ha}$ de $\mathrm{N}(\mathrm{B}+100 \mathrm{~N})$, com $150 \mathrm{~kg} /$ ha de $\mathrm{N}(\mathrm{B}+150 \mathrm{~N})$; capim-jaraguá $(\mathrm{J})$ sem adubação nitrogenada $(\mathrm{J}+0 \mathrm{~N}), \operatorname{com} 50 \mathrm{~kg} / \mathrm{ha}$ de $\mathrm{N}$ $(\mathrm{J}+50 \mathrm{~N})$, com $100 \mathrm{~kg} / \mathrm{ha}$ de $\mathrm{N}(\mathrm{J}+100 \mathrm{~N})$, com $150 \mathrm{~kg} / \mathrm{ha}$ de $\mathrm{N}(\mathrm{J}+150 \mathrm{~N})$; e capim-braquiária e a leguminosa estilosantes (E) em consórcio $(B+E)$, e capim-jaraguá e a leguminosa estilosantes em consórcio $(\mathrm{J}+\mathrm{E})$.

O solo foi classificado em Latossolo Vermelho Amarelo distrófico (LVAd), textura argilosa (argila$53 \mathrm{dag} / \mathrm{kg}$ ), apresentando a seguinte composição química na camada de 0 a $20 \mathrm{~cm}$ de profundidade: $\mathrm{pH}$ $5,00\left(\mathrm{H}_{2} \mathrm{O}, 1: 2,5\right) ; \mathrm{P}, \mathrm{Ca}$ e Na (Mehlich-1) - 2,40, 44,00 e $7,00 \mathrm{mg} / \mathrm{dm}^{3}$, respectivamente; $\mathrm{Ca}, \mathrm{Mg}$ e $\mathrm{Al}$ $(\mathrm{KCl} 1 \mathrm{~mol} / \mathrm{L})-0,50,0,20$ e $0,70 \mathrm{cmol}_{\mathrm{c}} / \mathrm{dm}^{3} ; \mathrm{H}+\mathrm{Al}$ $\left[\mathrm{Ca}(\mathrm{OAc})_{2}-0,5 \mathrm{~mol} / \mathrm{L}-\mathrm{pH} 7\right]-6,70 \mathrm{cmol}_{\mathrm{c}} / \mathrm{dm}^{3} ; \mathrm{SB}$, CTC Efetiva e a pH $7-0,84,1,54$ e 7,57 $\mathrm{cmol}_{\mathrm{c}} / \mathrm{dm}^{3}$; Saturação por bases e por alumínio - 11,40 e 43,70\%; $\mathrm{Zn}, \mathrm{Fe}, \mathrm{Mn}$ e Cu (Mehlich-1) - 2,15, 123,00, 15,50 e $2,45 \mathrm{mg} / \mathrm{dm}^{3}$ (Análises realizadas nos laboratórios do Departamento de Solos - UFV).

Antes da delimitação dos blocos e demarcação das parcelas (10 x $10 \mathrm{~m})$, foi feita uma avaliação da cobertura do solo e distribuição da vegetação na área experimental com base na metodologia descrita por Mannetje \& Haydock (1963). Foram alocados 90 quadrados de 0,5 m de lado na pastagem, e avaliou-se o grau de degradação pela estimativa visual. Os resultados revelaram que a área apresentava 10\% de capimgordura, $12 \%$ de capim-sapé (Imperata brasiliensis Trin.), $7 \%$ de outras forrageiras, $5 \%$ de outras plantas daninhas e $66 \%$ sem nenhuma vegetação.

Em outubro/98, foi ateado fogo na vegetação da área experimental, conforme recomendação de Cruz Filho et al. (1986) e Cóser \& Cruz Filho (1989), que alertam para os riscos de erosão em solos de topografia acidentada, quando se utiliza aração total para eliminar plantas indesejáveis. Em seguida, procedeu-se à correção do solo com aplicação de 1,7 t/ha de calcário dolomítico (PRNT 100\%), a lanço, espalhado uniformemente em toda área experimental. Posteriormente, em novembro/98, foram abertos sulcos em curva de nível (utilizando um sulcador reversível de tração animal, ou seja, tracionado por uma junta de bois), espaçados de $1 \mathrm{~m}$ e com 15 a $20 \mathrm{~cm}$ de profundidade, onde foi aplicado adubo fosfatado, $(450 \mathrm{~kg} / \mathrm{ha}$ de superfosfato simples direcionado para o fundo do sulco de semeadura). No início das chuvas (novembro), foi executada a semeadura das espécies no interior dos sulcos, utilizandose taxa correspondente a quatro, quatro e dois $\mathrm{kg} / \mathrm{ha}$ de sementes comerciais de capim-braquiária, capimjaraguá e estilosantes, respectivamente. Nas parcelas correspondentes aos consórcios, a semeadura das gramíneas foi efetuada em sulcos alternados com os 
da leguminosa. Em janeiro de 1999, realizou-se corte de uniformização em todas as plantas da área a aproximadamente $20 \mathrm{~cm}$ do nível do solo.

O adubo potássico foi aplicado em cobertura, sem parcelamento, em janeiro/99, na dose de $105 \mathrm{~kg} / \mathrm{ha}$ de cloreto de potássio misturado com micronutrientes (30 kg/ha de FTE BR 12). A adubação nitrogenada (uréia) foi parcelada em apenas duas aplicações, em meados de janeiro e março/99, em decorrência da irregularidade das chuvas.

As avaliações foram realizadas em duas colheitas; a primeira (16/08/99 - período seco) foi realizada oito meses depois do corte de uniformização e a segunda (08/12/99 - período chuvoso), quatro meses após a primeira. As datas das colheitas não foram fixas, porque sua realização dependia antes de uma avaliação visual da distribuição das forrageiras introduzidas na pastagem. O método de amostragem utilizado foi o peso real (Gardner, 1986), executado com o auxílio de uma unidade amostral metálica, de forma retangular e de tamanho 2,0 $\mathrm{m}$ x 0,5 $\mathrm{m}\left(1 \mathrm{~m}^{2}\right)$. A amostragem utilizada foi do tipo sistemática, conforme revisão proposta por Nascimento Jr. (1991). As colheitas foram efetuadas a $20 \mathrm{~cm}$ do nível do solo, eliminando-se a bordadura, constituída dos dois sulcos laterais e de $1 \mathrm{~m}$ de cada extremidade da parcela. Posteriormente, no laboratório, as plantas foram separadas nos seguintes grupos: 1) capim-braquiária; 2) capim-jaraguá; 3) estilosantes; 4) capim-gordura; 5) capim-sapé; 6) outras plantas daninhas; 7) outras forrageiras. Após cada colheita, foi efetuado um corte com roçadeira do tipo costal, para eliminar o restante das plantas não colhidas nas parcelas, seguido da remoção do material vegetal da área, por meio de ancinhos.

Depois da separação das plantas após a colheita, retiraram-se amostras em cada grupo, as quais foram submetidas à secagem a $60^{\circ} \mathrm{C}$ até peso constante. As amostras de toda a parte aérea das forrageiras introduzidas na pastagem, do capim-gordura e do capim-sapé foram utilizadas para o cálculo da produção de matéria seca (MS), em kg/ha. Apenas para as forrageiras introduzidas, as amostras foram analisadas quanto aos teores de proteína bruta (PB), fibra em detergente neutro (FDN), fibra em detergente ácido (FDA), fósforo $(\mathrm{P})$, potássio $(\mathrm{K})$, cálcio $(\mathrm{Ca})$ e magnésio $(\mathrm{Mg})$, segundo recomendações de Silva \& Queiroz (2002). Para análise dos minerais P, K, Ca e $\mathrm{Mg}$, as amostras foram mineralizadas por via úmida (4 $\mathrm{mL} \mathrm{HNO}_{3}$ concentrado e $1 \mathrm{~mL} \mathrm{HClO}_{4} 70-72 \%$ para 0,2 g de MS) e as soluções resultantes, devidamente diluídas, tiveram seus teores de $\mathrm{P}$ dosados por colorimetria, de $\mathrm{K}$ por fotometria de chama e de $\mathrm{Ca}$ e $\mathrm{Mg}$ por espectrofotometria de absorção atômica.

Os valores das produções de MS, em $\mathrm{kg} / \mathrm{ha}$, das forrageiras de cada consórcio (gramínea e leguminosa) foram somados, objetivando avaliar a produção total do consórcio. Para os teores de PB, FDN, FDA, P, K, Ca e $\mathrm{Mg}$ nos tratamentos correspondentes aos consórcios, os cálculos foram efetuados usando-se a seguinte fórmula, $\mathrm{MP}=\left[\left(\mathrm{W}_{1} \times \mathrm{MS}_{1}\right)+\left(\mathrm{W}_{2} \times \mathrm{MS}_{2}\right)\right] / \mathrm{MS}_{1}+$ $\mathrm{MS}_{2}$, em que: $\mathrm{MP}=$ média ponderada da característica avaliada; $\mathrm{W}_{1}$ e $\mathrm{W}_{2}=$ valores da característica avaliada encontrados para gramínea e leguminosa introduzidas, respectivamente; $\mathrm{MS}_{1}$ e $^{\mathrm{MS}} \mathrm{S}_{2}=$ valores das produções de MS (kg/ha) encontrados para gramínea e leguminosa introduzidas, respectivamente.

Os efeitos das doses de $\mathrm{N}$ dentro de cada gramínea foram analisados ajustando-se equações de regressão e adotando-se os modelos com coeficientes significativos a $5 \%$ de probabilidade pelo teste te com maiores valores para o coeficiente de determinação $\left(\mathrm{R}^{2}\right)$. Para os tratamentos envolvendo os consórcios não incluídos no fatorial, foi utilizado o teste $\mathrm{F}$ a 5 ou a $1 \%$ de probabilidade. Para o contraste Fatorial vs Consórcio, foi aplicado o teste de Dunnett ao nível de $5 \%$ de probabilidade. Assim, as médias dos tratamentos do fatorial foram comparadas com a média do consórcio capim-braquiária e estilosantes $(B+E)$ e com a média do consórcio capim-jaraguá e estilosantes $(\mathrm{J}+\mathrm{E})$. Todas as análises foram realizadas por meio do programa SAEG (Euclides, 2003).

\section{Resultados e Discussão}

Na primeira colheita (período seco), o rendimento forrageiro do capim-braquiária aumentou linearmente $(\mathrm{P}<0,01)$ até $4.604 \mathrm{~kg} / \mathrm{ha}$ de MS. Isso comprova o potencial de resposta dessa forrageira à aplicação de N, conforme constatado por Fernandes et al. (1985) e Alvim et al. (1990). Por outro lado, não houve efeito significativo $(\mathrm{P}>0,05)$ sobre as produções de MS do capim-gordura. O capim-sapé, entretanto, apresentou pequena resposta na produção de MS e de forma quadrática $(\mathrm{P}<0,05)$ (Tabela 2$)$, indicando que essa planta daninha utilizou parte do $\mathrm{N}$ aplicado para incrementar sua produção até a dose de $79,1 \mathrm{~kg} / \mathrm{ha}$ de $\mathrm{N}$, com produção máxima estimada de $1.004 \mathrm{~kg} / \mathrm{ha} \mathrm{de}$ MS, valor próximo ao da produção do capim-gordura (998 kg/ha de MS).

\section{R. Bras. Zootec., v.34, n.2, p.442-453, 2005}


Tabela 2 - Equações de regressão das produções de matéria seca (MS - kg/ha) das gramíneas avaliadas nos tratamentos com capim-braquiária e capim-jaraguá, em função das doses de nitrogênio, na primeira e segunda colheitas

Table 2 - Regression equations for dry matter yields (DM - $\mathrm{kg} / \mathrm{ha}$ ) of the grasses evaluated in treatments with $B$. decumbens and Hyparrhenia rufa as a function of nitrogen doses, in the first and second harvests

\begin{tabular}{|c|c|c|c|c|}
\hline \multirow{2}{*}{$\begin{array}{l}\text { Característica } \\
\text { Characteristic }\end{array}$} & \multicolumn{2}{|c|}{$\begin{array}{l}\text { Primeira colheita } \\
\text { First harvest }\end{array}$} & \multicolumn{2}{|c|}{$\begin{array}{l}\text { Segunda colheita } \\
\text { Second harvest }\end{array}$} \\
\hline & $\begin{array}{l}\text { Equação } \\
\text { Equation }\end{array}$ & $\mathrm{R}^{2}$ & $\begin{array}{l}\text { Equação } \\
\text { Equation }\end{array}$ & $\mathrm{R}^{2}$ \\
\hline \multicolumn{5}{|c|}{$\begin{array}{l}\text { Capim-braquiária + Nitrogênio } \\
\text { Brachiaria dcumbens + Nitrogen }\end{array}$} \\
\hline $\begin{array}{l}\text { MS - Braquiária } \\
D M-B . \text { decumbens }\end{array}$ & $\mathrm{Y}=1.531,4+21,0 * * \mathrm{~N}$ & 0,95 & $\mathrm{Y}=990,3+30,3 * * \mathrm{~N}-0,1 * * \mathrm{~N}^{2}$ & 0,98 \\
\hline $\begin{array}{l}\text { MS - Capim-gordura } \\
\text { DM - Melinis minutiflora }\end{array}$ & $\mathrm{Y}=998,6$ & - & $\mathrm{Y}=349,1$ & - \\
\hline $\begin{array}{l}\text { MS - Capim-sapé } \\
\text { DM - Imperata brasiliensis }\end{array}$ & 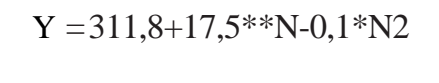 & 0,65 & $Y=506,1$ & - \\
\hline \multicolumn{5}{|c|}{$\begin{array}{l}\text { Capim-jaraguá }+ \text { Nitrogênio } \\
\text { Hyparrhenia rufa }+ \text { Nitrogen }\end{array}$} \\
\hline $\begin{array}{l}\text { MS - Jaraguá } \\
D M-H . \text { rufa }\end{array}$ & $\mathrm{Y}=995,6$ & - & $\mathrm{Y}=782,7$ & - \\
\hline $\begin{array}{l}\text { MS - Capim-gordura } \\
\text { DM - Melinis minutiflora }\end{array}$ & $\mathrm{Y}=1.015,4+29,8 * * \mathrm{~N}-0,1 * * \mathrm{~N} 2$ & 0,63 & $\mathrm{Y}=348,7$ & - \\
\hline $\begin{array}{l}\text { MS - Capim-sapé } \\
\text { DM - Imperata brasiliensis }\end{array}$ & $Y=952,0$ & - & $\mathrm{Y}=505,7$ & - \\
\hline
\end{tabular}

*, ** Significativo a 5 e $1 \%$ de probabilidade pelo teste $t$, respectivamente.

$*, * *$ Significant at 5 and $1 \%$ probability by $t$ test, respectively.

A moderada competição entre capim-sapé e capim-braquiária, refletida na primeira colheita era esperada, pois em método de preparo parcial do solo, na fase de formação da pastagem a forrageira introduzida fica em desvantagem, em relação às demais plantas existentes e estabelecidas na área. Assim, o capim-braquiária adubado com $50 \mathrm{~kg} / \mathrm{ha}$ de $\mathrm{N}$ produziu, em uma única colheita, $2.996 \mathrm{~kg} / \mathrm{ha}$ de MS. Esse valor foi superior aos de Botrel et al. (1994), que encontraram $2.630 \mathrm{~kg} / \mathrm{ha}$ de MS com adubação semelhante. Portanto, no presente estudo, constata-se que houve boa adaptação e resposta do capim-braquiária ao $\mathrm{N}$ aplicado, pois o preparo do solo foi parcial e havia elevada presença de plantas daninhas na pastagem. Botrel et al. (1994), por sua vez, trabalharam com solo arado e gradeado, onde as plantas daninhas foram totalmente eliminadas.

Na segunda colheita (período chuvoso), o rendimento forrageiro do capim-braquiária aumentou de forma quadrática $(\mathrm{P}<0,01)$ em resposta à aplicação de $\mathrm{N}$, com produção máxima estimada em $2.759 \mathrm{~kg} /$ ha de MS, para uma dose de $101 \mathrm{~kg} / \mathrm{ha}$ de N. Entretanto, não foram observados efeitos significativos $(\mathrm{P}>0,05)$ das doses de $\mathrm{N}$ sobre as produções de MS do capim-gordura e capimsapé (Tabela 2). A relação da produção de MS do capim-sapé com as doses de $\mathrm{N}$ aplicadas, constatada na primeira colheita, não se confirma na segunda, após estabelecimento do capim-braquiária na área. Isso indica que o capim-sapé, ao longo do período experimental, não aproveitou maiores quantidades de nutrientes disponíveis no solo para convertê-los em biomassa, e diminuiu sua competitividade, principalmente associado com forrageiras responsivas, corroborando estudos de Bogdan (1977) e Cruz Filho et al. (1986).

A máxima produção de MS estimada para o capimbraquiária $(2.759 \mathrm{~kg} / \mathrm{ha})$ foi bem inferior à maior produção constatada na primeira colheita $(4.604 \mathrm{~kg} / \mathrm{ha})$. De modo geral, as produções de MS na segunda colheita, em todos os tratamentos, foram inferiores às da primeira. Tal situação evidencia baixo efeito residual da adubação nitrogenada, uma vez que essa foi efetuada apenas antes do primeira colheita (janeiro e março/99). Portanto, pode-se admitir que perdas devem ter ocorrido, o que, conseqüentemente, contribuiu para reduzir a produção forrageira.

Para o capim-jaraguá, tanto na primeira quanto na segunda colheita, não se detectou influência $(\mathrm{P}>0,05)$ das doses de $\mathrm{N}$ sobre as produções de MS. Por outro lado, os dados de produção das outras plantas existentes na área ajustaram-se $(\mathrm{P}<0,01)$ ao 
modelo quadrático apenas para o capim-gordura na primeira colheita (Tabela 2). O capim-jaraguá atingiu produções bastante modestas em todos os tratamentos, provavelmente em função da baixa densidade populacional de plantas estabelecidas na área, fato verificado durante a condução do experimento. Isso pode ter contribuído para menor aproveitamento do $\mathrm{N}$, resultando em maiores perdas desse nutriente por volatilização e lixiviação, ou mesmo por absorção pelas outras gramíneas, o que foi evidenciado por Cruz Filho et al. (1986).

Quanto aos consórcios na primeira colheita (Tabela 3), o tratamento correspondente ao capimbraquiária e estilosantes $(\mathrm{B}+\mathrm{E})$, produziu $5.033 \mathrm{~kg}$ / ha de MS, sendo $1.271 \mathrm{~kg} / \mathrm{ha}(25 \%)$ para a gramínea e $3.762 \mathrm{~kg} / \mathrm{ha}$ (75\%) para o estilosantes. Essa predominância do estilosantes na pastagem não foi observada em outros estudos semelhantes (Botrel et al., 1994; Cantarutti \& Boddey, 1997). Acresce-se ainda que a produção de MS do consórcio foi superior $(\mathrm{P}<0,05)$ às produções do capim-braquiária e capimjaraguá sem adubação nitrogenada e do capim-jaraguá adubado com 50, 100 e $150 \mathrm{~kg} / \mathrm{ha}$ de N (Tabela 3). A elevada produção de MS da leguminosa no consórcio explica essa superioridade. O consórcio com capimjaraguá $(\mathrm{J}+\mathrm{E})$, por sua vez, atingiu $3.751 \mathrm{~kg} / \mathrm{ha}$ de MS, com $208 \mathrm{~kg} / \mathrm{ha}(5,5 \%)$ para a gramínea e $3.543 \mathrm{~kg} / \mathrm{ha}$ $(94,5 \%)$ para a leguminosa. A produção nesse consórcio $(\mathrm{J}+\mathrm{E})$ foi superior $(\mathrm{P}<0,05)$ apenas às dos tratamentos capim-jaraguá sem adubação nitrogenada e adubado com $100 \mathrm{~kg} / \mathrm{ha}$ de N. Esses resultados indicam a importância da leguminosa na pastagem, principalmente quando não se fornece adubo nitrogenado para a gramínea. Gomide et al. (1984b), em trabalho no campo, também verificaram que os consórcios capimjaraguá com centrosema ou com soja perene foram superiores apenas ao tratamento da gramínea pura, sem adubação nitrogenada (testemunha).

Na segunda colheita (Tabela 3), quando a produção de MS do consórcio capim-braquiária e estilosantes foi comparada às produções das duas gramíneas adubadas com $\mathrm{N}$, os resultados obtidos seguiram mesma tendência da colheita anterior, porém com valores menos expressivos. O consórcio $(\mathrm{B}+\mathrm{E})$ produziu $2.150 \mathrm{~kg} / \mathrm{ha}$ de MS $(997 \mathrm{~kg} / \mathrm{ha}-46 \%$ - para a gramínea e $1.152 \mathrm{~kg} / \mathrm{ha}-54 \%$ - para a leguminosa). A produção de MS do consórcio capim-jaraguá e estilosantes foi inferior $(\mathrm{P}<0,05)$ apenas à do capimbraquiária adubado com $100 \mathrm{~kg} / \mathrm{ha}$ de $\mathrm{N}$, não diferindo $(\mathrm{P}>0,05)$ dos demais tratamentos.
Tabela 3 - Produções de matéria seca (MS) do capimbraquiária e do capim-jaraguá adubados com nitrogênio e dos consórcios com estilosantes, na primeira e segunda colheitas

Table 3 - Dry matter yields (DM) of Brachiaria decumbens and Hyparrhenis rufa fertilized with nitrogen and their mixtures with Stylosanthes guianensis in the first and second harvests

\begin{tabular}{|c|c|c|}
\hline $\begin{array}{l}\text { Tratamento } \\
\text { Treatment }\end{array}$ & $\begin{array}{l}\text { Primeira colheita } \\
\text { First harvest }\end{array}$ & $\begin{array}{l}\text { Segunda colheita } \\
\text { Second harvest }\end{array}$ \\
\hline $\begin{array}{l}B+E v s J+E \\
B+E^{1} \\
J+E^{2}\end{array}$ & $\begin{array}{l}* * \\
5.033 \mathrm{a} \\
3.751 \mathrm{~A}\end{array}$ & $\begin{array}{c}\mathrm{ns} \\
2.150 \mathrm{a} \\
1.223 \mathrm{~A}\end{array}$ \\
\hline $\begin{array}{l}B+0 N^{3} \\
B+50 N \\
B+100 N \\
B+150 N \\
J+0 N \\
J+50 N \\
J+100 N \\
J+150 N\end{array}$ & $\begin{array}{c}1.824 \mathrm{bA} \\
2.996 \mathrm{aA} \\
3.547 \mathrm{aA} \\
4.604 \mathrm{aA} \\
618 \mathrm{bB} \\
1.030 \mathrm{bA} \\
887 \mathrm{bB} \\
1.445 \mathrm{bA}\end{array}$ & $\begin{array}{c}1.019 \mathrm{bA} \\
2.048 \mathrm{aA} \\
2.617 \mathrm{aB} \\
2.149 \mathrm{aA} \\
522 \mathrm{bA} \\
750 \mathrm{bA} \\
715 \mathrm{bA} \\
1.142 \mathrm{bA}\end{array}$ \\
\hline $\begin{array}{l}\text { Média } \\
\text { Mean }\end{array}$ & 2.520 & 1.433 \\
\hline 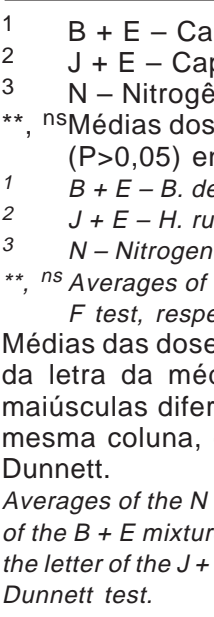 & $\begin{array}{l}\text { pim-braquiária e estilo } \\
\text { im-jaraguá e estilosar } \\
\text { nio (kg/ha). } \\
\text { consórcios, na coluna } \\
\text { tre si pelo teste } \mathrm{F} \text {, re } \\
\text { cumbens and stylosanth } \\
\text { fa and Stylosanthes unde } \\
\text { (kg/ha). } \\
\text { he mixtures in column di } \\
\text { ctively. } \\
\text { s de } \mathrm{N} \text { seguidas de let } \\
\text { lia do consórcio B + } \\
\text { entes da letra da méd } \\
\text { diferem (P<0,05) de C } \\
\text { doses followed by small I } \\
\text { e average and followed b } \\
\text { E mixture average in the s }\end{array}$ & $\begin{array}{l}\text { tes em consórcio. } \\
\text { em consórcio. } \\
\text { erem }(P<0,01) \text { ou não } \\
\text { ctivamente. } \\
\text { dder mixture system. } \\
\text { xture system. } \\
(P<.01) \text { or not }(P>.05) \text { by } \\
\text { ninúsculas diferentes } \\
\text { seguidas de letras } \\
\text { o consórcio } \mathrm{J}+\mathrm{E} \text {, na } \\
\text { consórcio pelo teste } \\
\text { s differing from the letter } \\
\text { ital letters differing from } \\
\text { column differ }(P<.05) \text { by }\end{array}$ \\
\hline
\end{tabular}

Não se identificou um fator claro que explicasse essa alta produção de MS do capim-braquiária em um tratamento intermediário (Tabela 3), visto que o capimgordura e capim-sapé oriundos da pastagem tiveram participação homogênea em todos os tratamentos. No entanto, pode-se inferir, nesse caso, a ocorrência de maior efeito residual do N. O consórcio produziu $1.223 \mathrm{~kg} / \mathrm{ha}$ (196 kg/ha - 16\% - para o capim-jaraguá e $1.027 \mathrm{~kg} / \mathrm{ha}-84 \%$ - para a leguminosa). Verifica-se que o rendimento forrageiro da leguminosa nos dois consórcios, na segunda colheita, foi bastante reduzido em relação à colheita anterior, o que também foi constatado por Gomide et al. (1984b), que argumentam sobre a pouca persistência de leguminosas ao longo dos anos em consórcios com gramíneas em 
pastagens. De modo geral, as produções médias de MS dos dois consórcios foram incrementadas em $42,62 \%$ e $15,00 \%$, respectivamente, para a primeira e segunda colheitas, quando comparadas com as médias das produções das gramíneas adubadas. Na comparação entre os dois consórcios, houve superioridade $(\mathrm{P}<0,05)$ daquele entre leguminosa e capim-braquiária apenas na primeira colheita.

Os teores de PB do capim-braquiária, na primeira colheita, e do capim-jaraguá, na primeira e segunda colheitas, aumentaram linearmente $(\mathrm{P}<0,01)$ com a adubação nitrogenada (Tabela 4). Resultados semelhantes foram relatados por Silva (1983), Gomide et al. (1984a) e Gomide et al. (1984b), que demonstraram efeito positivo do $\mathrm{N}$ sobre o teor de proteína em gramíneas. Na segunda colheita, a não resposta $(\mathrm{P}>0,05)$ do capim-braquiária à adubação nitrogenada indica possível limite fisiológico da forrageira em concentrar teores de $\mathrm{N}$ muito acima de $1,44 \mathrm{dag} / \mathrm{kg}(9,0 \mathrm{dag} / \mathrm{kg}$ de PB) na sua parte aérea, conforme discutido por Brockington et al. (1986), embora a média encontrada de 7,80 dag/kg (Tabela 4) não seja considerada baixa para tal espécie admitindo que os fatores de ambiente (luz, água, temperatura, nutrientes, etc.) não tenham sido limitantes (período chuvoso). Entretanto, na primeira colheita (período seco), os teores de PB das gramíneas situaram-se abaixo de 3,5 dag $/ \mathrm{kg}$, valores considerados baixos e que podem ser atribuídos à idade avançada das plantas (240 dias) e à época da colheita, quando os fatores de ambiente geralmente limitam a rebrotação e renovação de perfilhos na pastagem, comprometendo a qualidade do pasto. Por outro lado, na segunda colheita (período chuvoso), as duas gramíneas atingiram teores acima de 7,0 dag/kg, mínimo neces- sário para atuação dos microorganismos ruminais na produção de proteína microbiana (Milford \& Minson, 1966). Portanto, sugere-se que as forrageiras atenderiam às exigências de bovinos em pastejo para esse nutriente. Além disso, é oportuno enfatizar que os animais selecionam plantas e partes de plantas com maiores concentrações de $\mathrm{N}$ e outros nutrientes, melhorando a qualidade de sua dieta.

Os teores de PB das forrageiras nos dois consórcios foram muito superiores $(\mathrm{P}<0,05)$ aos valores obtidos para as gramíneas adubadas com $\mathrm{N}$, tanto na primeira colheita (Tabela 5) quanto na segunda (Tabela 6). A superioridade do consórcio, vinculada principalmente à leguminosa, também foi constatada em trabalhos desenvolvidos por Gomide et al. (1984b), Gomide et al. (1984c) e Boddey et al. (1993), pois, em geral, as leguminosas apresentam menor queda da qualidade com a maturidade fisiológica e têm boa capacidade de absorção de água mesmo em condições climáticas adversas (Andrade, 1982). A fixação biológica de $\mathrm{N}_{2}$ por bactérias em simbiose com leguminosas forrageiras também fornecem subsídios para o atendimento de suas exigências (Cantarutti \& Boddey, 1997).

O teor de PB do consórcio capim-jaraguá e estilosantes foi significativamente maior $(\mathrm{P}<0,05)$ que o do consórcio capim-braquiária e estilosantes, nas duas colheitas (Tabelas 5 e 6). Isso se deve à menor participação do capim-jaraguá na produção de MS do consórcio (208 e 196 kg/ha na primeira e segunda colheitas, respectivamente). Apesar de os valores de PB do estilosantes nos dois consórcios terem se aproximado, a produção de MS do capimbraquiária (1.271 e $997 \mathrm{~kg} / \mathrm{ha}$ nas duas colheitas, respectivamente) contribuiu para reduzir a média pon-

Tabela 4 - Equações de regressão das concentrações de proteína bruta (PB - dag/kg) do capim-braquiária e do capimjaraguá em função das doses de nitrogênio, na primeira e segunda colheitas

Table 4 - Regression equations of the crude protein concentrations (CP-dag/ $\mathrm{kg}$ ) of the Brachiaria decumbens and Hyparrhenia rufa as a function of the $N$ doses, in the first and second harvests

\begin{tabular}{|c|c|c|c|c|}
\hline \multirow{2}{*}{$\begin{array}{l}\text { Característica } \\
\text { Characteristic }\end{array}$} & \multicolumn{2}{|c|}{$\begin{array}{l}\text { Primeira colheita } \\
\text { First harvest }\end{array}$} & \multicolumn{2}{|c|}{$\begin{array}{l}\text { Segunda colheita } \\
\text { Second harvest }\end{array}$} \\
\hline & $\begin{array}{l}\text { Equação } \\
\text { Equation }\end{array}$ & $\mathrm{R}^{2}$ & $\begin{array}{l}\text { Equação } \\
\text { Equation }\end{array}$ & $\mathrm{R}^{2}$ \\
\hline $\begin{array}{l}\text { PB - Braquiária } \\
C P-B . \text { decumbens }\end{array}$ & $\mathrm{Y}=3,1473+0,0162 * * \mathrm{~N}$ & 0,98 & $Y=7,80$ & - \\
\hline $\begin{array}{l}\text { PB - Jaraguá } \\
C P-H . \text { rufa }\end{array}$ & $\mathrm{Y}=2,6640+0,0073 * * \mathrm{~N}$ & 0,91 & $Y=7,2156+0,0076 * \mathrm{~N}$ & 0,95 \\
\hline
\end{tabular}

${ }^{*},{ }^{* *}$ Significativo a 5 e $1 \%$ de probabilidade pelo teste $\mathrm{t}$, respectivamente.

*, ** Significant at 5 and $1 \%$ probability by $t$ test, respectively.

\section{R. Bras. Zootec., v.34, n.2, p.442-453, 2005}


derada de PB do consórcio entre essa gramínea e a leguminosa. Resultados de trabalhos realizados por Andrade (1982) e Boddey et al. (1993) aproximam-se daqueles encontrados no presente estudo.

Os teores de FDN do capim-braquiária ( $\mathrm{Y}=73,14$ e $67,67 \mathrm{dag} / \mathrm{kg}$ na primeira e segunda colheitas, respectivamente) e do capim-jaraguá ( $\mathrm{Y}=79,52$ e 68,80 $\mathrm{dag} / \mathrm{kg}$, nas duas colheitas, respectivamente) não foram influenciados $(\mathrm{P}>0,05)$ pela aplicação de $\mathrm{N}$. Nas duas colheitas, os teores de FDA não foram influenciados $(\mathrm{P}>0,05)$ pelas doses de $\mathrm{N}$ aplicadas ao capimbraquiária ( $\mathrm{Y}=37,66$ e $34,35 \mathrm{dag} / \mathrm{kg}$ ) e ao capimjaraguá ( $\mathrm{Y}=47,41$ e 38,63 dag $/ \mathrm{kg}$ ). Ribeiro et al. (1999) também não observaram acentuadas diferenças nos teores de FDN e de FDA do capim-elefante cv. Mott em resposta à adubação nitrogenada, considerando-se que suas concentrações são bastante elevadas, graças à própria morfofisiologia dessa forrageira.

Por outro lado, os teores de FDN foram mais baixos $(\mathrm{P}<0,05)$ nos consórcios, comparados aos das gramíneas adubadas com $\mathrm{N}$, tanto na primeira colheita
(Tabela 5) quanto na segunda (Tabela 6). As grandes diferenças observadas entre os tratamentos comparados são atribuídas à maior participação do estilosantes, que apresentou menores teores de FDN relativos aos das gramíneas. Assim, para a primeira e segunda colheitas, respectivamente, os teores de FDN da leguminosa foram de 62 e $51 \mathrm{dag} / \mathrm{kg}$, enquanto o capim-braquiária apresentou média de 76 e 68 dag/ kg. No consórcio com capim-jaraguá, os teores de FDN foram de 60 e $55 \mathrm{dag} / \mathrm{kg}$ para o estilosantes e média de 74 e 69 dag/kg para a gramínea. Comparando os dois consórcios entre si, o teor de FDN do consórcio capim-braquiária e estilosantes foi superior $(\mathrm{P}<0,05)$ ao do capim-jaraguá e estilosantes apenas na primeira colheita (Tabela 5), graças ao maior incremento de MS do capim-braquiária nesse consórcio que, como mencionado, atingiu altas concentrações de FDN na parte aérea.

Wendling (1997) encontrou teor de FDN igual a $70,10 \mathrm{dag} / \mathrm{kg}$ em pastagem formada de capimbraquiária. Todos os resultados do presente trabalho

Tabela 5 - Concentrações de proteína bruta (PB), fibra em detergente neutro (FDN), fibra em detergente ácido (FDA), fósforo $(P)$, potássio $(K)$, cálcio $(\mathrm{Ca})$ e magnésio $(\mathrm{Mg})$ na matéria seca $(\mathrm{MS})$ do capim-braquiária e do capimjaraguá adubados com nitrogênio e dos consórcios com estilosantes, na primeira colheita

Table 5 - Concentrations of crude protein $(C P)$, neutral detergent fiber (NDF), acid detergent fiber (ADF), phosphorus (P), potassium $(K)$, calcium $(\mathrm{Ca})$ and magnesium $(\mathrm{Mg})$ in the dry matter $(\mathrm{DM})$ of either $\mathrm{B}$. decumbens and $\mathrm{H}$. rufa fertilized with nitrogen and the mixture with $S$. guianensis, in the first harvesting

\begin{tabular}{|c|c|c|c|c|c|c|c|}
\hline $\begin{array}{l}\text { Tratamento } \\
\text { Treatment }\end{array}$ & $\begin{array}{l}\mathrm{PB} \\
C P\end{array}$ & $\begin{array}{l}\text { FDN } \\
N D F\end{array}$ & $\begin{array}{l}\text { FDA } \\
A D F\end{array}$ & $\mathrm{P}$ & $\mathrm{K}$ & $\mathrm{Ca}$ & $\mathrm{Mg}$ \\
\hline \multicolumn{8}{|c|}{$\mathrm{dag} / \mathrm{kg}$} \\
\hline $\mathrm{B}+\mathrm{E}$ vs $\mathrm{J}+\mathrm{E}$ & $* *$ & * & $\mathrm{ns}$ & $\mathrm{ns}$ & $*$ & $\mathrm{~ns}$ & $\mathrm{~ns}$ \\
\hline$B+E^{1}$ & $7,63 \mathrm{a}$ & $65,3 \mathrm{a}$ & $44,0 \mathrm{a}$ & $0,08 \mathrm{a}$ & $0,73 \mathrm{a}$ & $0,78 \mathrm{a}$ & $0,18 \mathrm{a}$ \\
\hline$J+E^{2}$ & $8,96 \mathrm{~A}$ & $60,5 \mathrm{~A}$ & $42,3 \quad \mathrm{~A}$ & $0,07 \quad \mathrm{~A}$ & 0,89 A & $0,82 \mathrm{~A}$ & 0,16 A \\
\hline $\mathrm{B}+0 \mathrm{~N}^{3}$ & $3,18 \mathrm{~b} \mathrm{~B}$ & $73,0 \mathrm{~b} \mathrm{~B}$ & $36,7 \mathrm{~b} \mathrm{~B}$ & $0,11 \mathrm{bB}$ & 0,90 a A & $0,59 \mathrm{bB}$ & $0,27 \mathrm{~b} \mathrm{~B}$ \\
\hline $\mathrm{B}+50 \mathrm{~N}$ & 3,99 b B & $73,0 \mathrm{~b} \mathrm{~B}$ & 37,5 b B & 0,08 a A & 0,97 a A & $0,54 \mathrm{~b} \mathrm{~B}$ & 0,29 b B \\
\hline $\mathrm{B}+100 \mathrm{~N}$ & 4,59 b B & $73,8 \mathrm{~b} \mathrm{~B}$ & 38,8 b B & 0,07 a A & 0,67 a A & $0,52 \mathrm{~b} \mathrm{~B}$ & $0,29 \mathrm{~b} \mathrm{~B}$ \\
\hline $\mathrm{B}+150 \mathrm{~N}$ & 5,68 b B & $72,6 \mathrm{~b} \mathrm{~B}$ & 37,4 b B & 0,07 a A & 0,70 a A & $0,50 \mathrm{~b} \mathrm{~B}$ & $0,25 \mathrm{~b} \mathrm{~B}$ \\
\hline $\mathrm{J}+0 \mathrm{~N}$ & $2,53 \mathrm{~b} \mathrm{~B}$ & 79,3 b B & 47,5 a B & 0,06 a A & $0,51 \mathrm{bB}$ & $0,50 \mathrm{~b} \mathrm{~B}$ & 0,18 a $\mathrm{A}$ \\
\hline $\mathrm{J}+50 \mathrm{~N}$ & 3,24 b B & 79,3 b B & 47,5 a B & 0,06 a $\mathrm{A}$ & $0,46 \mathrm{~b} \mathrm{~B}$ & 0,48 b B & 0,17 a $A$ \\
\hline $\mathrm{J}+100 \mathrm{~N}$ & 3,36 b B & $79,7 \mathrm{~b} \mathrm{~B}$ & 47,3 a B & 0,05 a A & $0,43 \mathrm{~b} \mathrm{~B}$ & $0,43 \mathrm{~b} \mathrm{~B}$ & 0,18 a $\mathrm{A}$ \\
\hline $\mathrm{J}+150 \mathrm{~N}$ & 3,72 b B & 79,6 b B & $47,1 \mathrm{a} \mathrm{B}$ & 0,05 a A & $0,47 \mathrm{~b} \mathrm{~B}$ & $0,44 \mathrm{~b} \mathrm{~B}$ & $0,20 \mathrm{a} A$ \\
\hline $\begin{array}{l}\text { Média } \\
\text { Mean }\end{array}$ & 4,69 & 73,6 & 42,6 & 0,07 & 0,68 & 0,56 & 0,22 \\
\hline
\end{tabular}

1 B + E - Capim-braquiária e estilosantes em consórcio.

$2 \mathrm{~J}+\mathrm{E}-\mathrm{Capim}$-jaraguá e estilosantes em consórcio.

$3 \mathrm{~N}$ - Nitrogênio $(\mathrm{kg} / \mathrm{ha})$.

**, nsMédias dos consórcios, na coluna, diferem $(P<0,01)$ ou não $(P>0,05)$ entre si pelo teste $F$, respectivamente.

$B+E-B$. decumbens and stylosanthes under mixture system.

$J+E-H$. rufa and Stylosanthes under mixture system.

$N$ - Nitrogen $(\mathrm{kg} / \mathrm{ha})$.

**, ns Averages of the mixtures in column differ $(P<.01)$ or not $(P>.05)$ by $F$ test, respectively.

Médias das doses de $\mathrm{N}$ seguidas de letras minúsculas diferentes da letra da média do consórcio $\mathrm{B}+\mathrm{E}$ e seguidas de letras maiúsculas diferentes da letra da média do consórcio $J+E$, na mesma coluna, diferem $(P<0,05)$ de cada consórcio pelo teste Dunnett.

Means of $N$ doses followed by small letters different from the letter of the $B+E$ mixture mean and followed by capital letters different from the letter of the $J+E$ mixture mean in the same column differ $(P<.05)$ by Dunnett test.

R. Bras. Zootec., v.34, n.2, p.442-453, 2005 
Tabela 6 - Concentrações de proteína bruta (PB), fibra em detergente neutro (FDN), fibra em detergente ácido (FDA), fósforo $(\mathrm{P})$, potássio $(\mathrm{K})$, cálcio $(\mathrm{Ca})$ e magnésio $(\mathrm{Mg})$ na matéria seca $(\mathrm{MS})$ do capim-braquiária e do capimjaraguá adubados com nitrogênio e dos consórcios com estilosantes, na segunda colheita

Table 6 - Concentrations of crude protein (CP), neutral detergent fiber (NDF), acid detergent fiber (FDA), phosphorus (P), potassium (K), calcium (Ca) and magnesium $(\mathrm{Mg})$ in the dry matter (DM) of either $\mathrm{B}$. decumbens and $\mathrm{H}$. rufa grasses fertilized with nitrogen and the mixtures with $S$. guianensis in the second harvesting

\begin{tabular}{|c|c|c|c|c|c|c|c|}
\hline $\begin{array}{l}\text { Tratamento } \\
\text { Treatment }\end{array}$ & $\begin{array}{l}\mathrm{PB} \\
C P\end{array}$ & $\begin{array}{l}\mathrm{FDN} \\
N D F\end{array}$ & $\begin{array}{l}\text { FDA } \\
A D F\end{array}$ & $\mathrm{P}$ & $\mathrm{K}$ & $\mathrm{Ca}$ & $\mathrm{Mg}$ \\
\hline & & & dag/kg & & & & \\
\hline $\mathrm{B}+\mathrm{E} v \mathrm{~J} \mathrm{~J}+\mathrm{E}$ & $* *$ & Ns & $\mathrm{ns}$ & $\mathrm{ns}$ & $* *$ & $\mathrm{~ns}$ & $\mathrm{~ns}$ \\
\hline $\mathrm{B}+\mathrm{E} 1$ & $11,96 a$ & $58,9 \mathrm{a}$ & $34,1 \mathrm{a}$ & $0,18 \mathrm{a}$ & $1,55 \mathrm{a}$ & $1,01 \mathrm{a}$ & $0,25 \mathrm{a}$ \\
\hline $\mathrm{J}+\mathrm{E} 2$ & $14,70 \mathrm{~A}$ & $57,2 \mathrm{~A}$ & $34,7 \quad \mathrm{~A}$ & $0,17 \quad \mathrm{~A}$ & $1,15 \mathrm{~A}$ & $1,34 \mathrm{~A}$ & $0,23 \quad \mathrm{~A}$ \\
\hline $\mathrm{B}+0 \mathrm{~N} 3$ & $7,40 \mathrm{~b} \mathrm{~B}$ & $66,0 \mathrm{~b} \mathrm{~B}$ & 33,0 a A & 0,20 a A & $1,82 \mathrm{a} \mathrm{B}$ & $0,43 \mathrm{~b} \mathrm{~B}$ & 0,25 a $A$ \\
\hline $\mathrm{B}+50 \mathrm{~N}$ & $7,71 \mathrm{~b} \mathrm{~B}$ & $68,1 \mathrm{~b} \mathrm{~B}$ & 34,6 a A & 0,17 a $\mathrm{A}$ & 1,59 a B & $0,49 \mathrm{~b} \mathrm{~B}$ & 0,29 a $\mathrm{A}$ \\
\hline $\mathrm{B}+100 \mathrm{~N}$ & 7,75 b B & $67,9 \mathrm{~b} \mathrm{~B}$ & 34,5 a $\mathrm{A}$ & 0,16 a A & 1,30 a $\mathrm{A}$ & $0,55 \mathrm{~b} \mathrm{~B}$ & 0,32 a $A$ \\
\hline $\mathrm{B}+150 \mathrm{~N}$ & 8,33 b B & $68,5 \mathrm{~b} B$ & 35,0 a A & 0,15 a $\mathrm{A}$ & 1,30 a $\mathrm{A}$ & $0,56 \mathrm{~b} \mathrm{~B}$ & 0,31 a $\mathrm{A}$ \\
\hline $\mathrm{J}+0 \mathrm{~N}$ & 7,32 b B & $68,8 \mathrm{~b} \mathrm{~B}$ & $38,2 \mathrm{~b} \mathrm{~B}$ & 0,17 a $\mathrm{A}$ & $1,05 \mathrm{~b} \mathrm{~A}$ & $0,61 \mathrm{bB}$ & 0,19 a $A$ \\
\hline $\mathrm{J}+50 \mathrm{~N}$ & 7,48 b B & $68,1 \mathrm{~b} \mathrm{~B}$ & 38,4 b B & 0,15 a A & $0,99 \mathrm{~b} \mathrm{~A}$ & $0,63 \mathrm{~b} \mathrm{~B}$ & 0,19 a $\mathrm{A}$ \\
\hline $\mathrm{J}+100 \mathrm{~N}$ & 7,89 b B & $69,9 \mathrm{~b} \mathrm{~B}$ & $39,7 \mathrm{~b} B$ & $0,14 \mathrm{~b} \mathrm{~A}$ & $0,99 \mathrm{~b} \mathrm{~A}$ & $0,57 \mathrm{~b} \mathrm{~B}$ & 0,21 a A \\
\hline $\mathrm{J}+150 \mathrm{~N}$ & 8,45 b B & $68,2 \mathrm{~b} \mathrm{~B}$ & $38,1 \mathrm{~b} \mathrm{~B}$ & $0,13 \mathrm{~b} \mathrm{~A}$ & $0,98 \mathrm{~b} \mathrm{~A}$ & $0,65 \mathrm{~b} \mathrm{~B}$ & 0,23 a A \\
\hline Média & 8,89 & 66,2 & 36,0 & 0,16 & 1,27 & 0,68 & 0,23 \\
\hline
\end{tabular}

B + E - Capim-braquiária e estilosantes em consórcio.

$\mathrm{J}+\mathrm{E}$ - Capim-jaraguá e estilosantes em consórcio.

$\mathrm{N}$ - Nitrogênio (kg/ha).

**, nsMédias dos consórcios, na coluna, diferem $(P<0,01)$ ou não $(P>0,05)$ entre si pelo teste $F$, respectivamente.

$B+E-B$. decumbens and stylosanthes under mixture system.

$J+E-H$. rufa and Stylosanthes under mixture system.

$N$ - Nitrogen $(\mathrm{kg} / \mathrm{ha})$.

**, ns Averages of the mixtures in column differ $(P<.01)$ or not $(P>.05)$ by $F$ test, respectively.

Médias das doses de $\mathrm{N}$ seguidas de letras minúsculas diferentes da letra da média do consórcio $\mathrm{B}+\mathrm{E}$ e seguidas de letras maiúsculas diferentes da letra da média do consórcio $J+E$, na mesma coluna, diferem $(P<0,05)$ de cada consórcio pelo teste Dunnett.

Means of $N$ doses followed by small letters different from the letter of the $B+E$ mixture mean and followed by capital letters different from the letter of the $J+E$ mixture mean in the same column differ $(P<.05)$ by Dunnett test.

apresentaram valores similares. A FDN representa a fração química da forrageira que se correlaciona mais estreitamente com o consumo voluntário, sendo que valores acima de 55 a 60 dag/kg correlacionam-se de maneira negativa (Van Soest, 1965). Nas duas colheitas, os valores encontrados para os consórcios estiveram acima do valor crítico de $55 \mathrm{dag} / \mathrm{kg}$ e, portanto, o consumo voluntário das forrageiras em pastejo poderia ser limitado no caso de uma pressão de pastejo alta, que reduziria a seletividade dos bovinos.

As forrageiras do consórcio capim-braquiária e estilosantes, na primeira colheita (agosto/99), atingiram teor de FDA mais elevado $(\mathrm{P}<0,05)$ que os teores do capim-braquiária em função de $\mathrm{N}$. Também, o teor de FDA das forrageiras no consórcio capim-jaraguá e estilosantes foi superior $(\mathrm{P}<0,05)$ aos teores do capim-braquiária em função de $\mathrm{N}$, porém, inferior $(\mathrm{P}<0,05)$ aos teores de FDA do capim-jaraguá adubado com N (Tabela 5). Na segunda colheita (dezembro/99), de forma geral, as forrageiras dos dois consórcios apresentaram concentrações mais baixas
$(\mathrm{P}<0,05)$ de FDA que o capim-jaraguá adubado com $\mathrm{N}$ (Tabela 6). A partir da grande variação dos resultados, infere-se que os teores de FDA foram pouco influenciados pelo N, seja na forma de adubo químico, seja fixado por microrganismos. Comparando-se os consórcios entre si, não houve diferenças $(\mathrm{P}>0,05)$ nos teores de FDA em nenhuma das duas colheitas (Tabelas 5 e 6). Esse resultado era esperado, uma vez que os valores de FDA encontrados foram muito próximos para as três forrageiras introduzidas.

Os teores de $\mathrm{P}$ e de $\mathrm{K}$, na primeira colheita, variaram inversamente $(\mathrm{P}<0,01)$ com as doses de $\mathrm{N}$ apenas para o capim-braquiária, tendo os dados se ajustado às seguintes equações de regressão: $\mathrm{Y}$ (Fósforo) $=0,1033-0,00027^{* *} \mathrm{~N} ; \mathrm{R}^{2}=0,82$, sendo em dag $/ \mathrm{kg}$ e $\mathrm{N}$ em kg/ha e Y (Potássio) $=0,9495$ $0,00178^{* *} \mathrm{~N} ; \mathrm{R}^{2}=0,66$, sendo em dag/kg e N em kg/ha. $\mathrm{Na}$ segunda colheita, os teores de $\mathrm{P}$ variaram inversamente com as doses de $\mathrm{N}$ para as duas gramíneas, com valores de 0,20 a $0,15 \mathrm{dag} / \mathrm{kg}$ para capimbraquiária $(\mathrm{P}<0,01)$ e de 0,16 a $0,13 \mathrm{dag} / \mathrm{kg}$ para capim-jaraguá $(\mathrm{P}<0,05)$, segundo as equações: 
$\mathrm{Y}($ Capim-braquiária $)=0,1954-0,00032 * * \mathrm{~N}$; $\mathrm{R}^{2}=0,88$, sendo em dag/kg e N em kg/ha e Y (Capimjaraguá) $=0,1635-0,00022 * \mathrm{~N} \mathrm{R}^{2}=0,95$, sendo em $\mathrm{dag} / \mathrm{kg}$ e $\mathrm{N}$ em $\mathrm{kg} / \mathrm{ha}$. No entanto, os teores de $\mathrm{K}$ variaram inversamente $(\mathrm{P}<0,01)$ com as doses de $\mathrm{N}$ apenas no capim-braquiária, segundo a equação: $\mathrm{Y}=1,7804-0,00375^{* *} \mathrm{~N} \mathrm{R}^{2}=0,91, \mathrm{em} \mathrm{dag} / \mathrm{kg}$ e $\mathrm{N}$ $\mathrm{em} \mathrm{kg} / \mathrm{ha}$. Os decréscimos nos teores dos minerais $\mathrm{P}$ e $\mathrm{K}$ do capim-braquiária nas duas colheitas e $\mathrm{P}$ do capim-jaraguá na segunda colheita podem ser atribuídos ao processo natural de diluição propiciado pela maior produção de MS, correlacionada às doses de $\mathrm{N}$ aplicadas (Fonseca et al., 1992).

As forrageiras dos dois consórcios atingiram teores de $\mathrm{P}$ mais elevados $(\mathrm{P}<0,05)$ que as gramíneas que não receberam adubação nitrogenada, mas apenas na primeira colheita. Na segunda colheita, em geral, não houve diferenças $(\mathrm{P}>0,05)$ marcantes entre consórcios e gramíneas adubadas com $\mathrm{N}$ (Tabelas 5 e 6). $\mathrm{Na}$ primeira colheita, os dois consórcios apresentaram maiores $(\mathrm{P}<0,05)$ teores de $\mathrm{K}$ que todos os tratamentos referentes ao capim-jaraguá adubado com $\mathrm{N}$ (Tabela 5), fato também verificado em estudos realizados por Gomide et al. (1984c).

Os teores de Ca não foram influenciados $(\mathrm{P}>0,05)$ pelas doses de $\mathrm{N}$ aplicadas ao capim-braquiária $(\mathrm{Y}=0,535 \mathrm{dag} / \mathrm{kg}$ ) na primeira colheita e ao capimjaraguá nas duas colheitas $(\mathrm{Y}=0,464$ e $0,611 \mathrm{dag} / \mathrm{kg}$, respectivamente). Estes resultados estão de acordo com os de Ribeiro et al. (1999), que não encontraram tendência definida quanto aos efeitos do $\mathrm{N}$ sobre a concentração de Ca no capim-elefante cv. Mott. Contudo, os teores de Ca do capim-braquiária na segunda colheita variaram diretamente $(\mathrm{P}<0,05)$ com as doses de $\mathrm{N}$, segundo a seguinte equação: $\mathrm{Y}=0,4424+0,00087 * \mathrm{~N}$ $\mathrm{R}^{2}=0,92$, sendo em dag/kg e $\mathrm{N}$ em $\mathrm{kg} / \mathrm{ha}$.

Os teores de $\mathrm{Mg}$ do capim-braquiária ( $\mathrm{Y}=0,275 \mathrm{dag} / \mathrm{kg}$ ) na primeira colheita e do capimjaraguá nas duas colheitas ( $\mathrm{Y}=0,182$ e 0,204 dag/kg, respectivamente) também não variaram $(\mathrm{P}>0,05)$, no entanto, para o capim-braquiária na segunda colheita houve significância $(\mathrm{P}<0,05)$ e ajustou-se a seguinte equação: $\mathrm{Y}=0,2677+0,00039^{*} \mathrm{~N}$; $\mathrm{R}^{2}=0,67$, em dag/kg e N em kg/ha. Os valores de Mg na MS do capim-braquiária em todas as doses de $\mathrm{N}$, nas duas colheitas, estão acima do nível crítico de 0,20 dag/kg (Woodson, citado por Neptune, 1986), abaixo do qual a forrageira não atende às exigências de bovinos em pastejo.

As forrageiras dos dois consórcios (nas duas colheitas) atingiram teores de Ca muito mais elevados $(\mathrm{P}<0,05)$ que as duas gramíneas adubadas com $N$. Esses resultados eram esperados, uma vez que a leguminosa é normalmente mais rica em Ca que as gramíneas (Gomide et al., 1979) e houve maior participação da mesma no rendimento forrageiro dos consórcios. Portanto, quando comparados entre si, não houve diferenças $(\mathrm{P}>0,05)$ nas duas colheitas (Tabelas 5 e 6). É importante considerar que os teores de Ca nos consórcios estão muito acima do nível crítico de $0,40 \mathrm{dag} / \mathrm{kg}$ relatado por Gomide et al. (1984c). Marschner (1995) explica que as gramíneas apresentam baixa capacidade de troca de cátions na raiz (CTC de raiz), e os solos, principalmente os mais argilosos, adsorvem mais fortemente no seu colóide cátions com valência maior $\left(\mathrm{Al}^{+3}>\mathrm{Ca}^{+2}>\mathrm{K}^{+}\right)$. Portanto, as gramíneas seriam mais eficientes na remoção de cátions monovalentes $\left(\mathrm{K}^{+}\right)$do solo, por competição por sítios de ligação, que poderiam interferir negativamente na absorção de $\mathrm{Ca}$, caracterizando o antagonismo entre os nutrientes.

Os teores de $\mathrm{Mg}$ das forrageiras nos dois consórcios foraminferiores $(\mathrm{P}<0,05)$ aos teores do capim-braquiária adubado com N, na primeira colheita (Tabela 5). Pode-se atribuir os baixos valores ponderados do consórcio à leguminosa, o que levou à superioridade do capimbraquiária nos tratamentos em função de N. Na segunda colheita (Tabela 6), não houve diferenças $(\mathrm{P}>0,05)$ entre os dois consórcios e os demais tratamentos.

\section{Conclusões}

O capim-braquiária respondeu satisfatoriamente às doses de $\mathrm{N}$ aplicadas e mostrou-se produtivo e adaptado às condições edafoclimáticas da região de Viçosa-MG, reduzindo a presença do capim-sapé na pastagem.

$\mathrm{O}$ capim-jaraguá não apresentou resposta ao $\mathrm{N}$ aplicado, evidenciando a necessidade de se fazer mais estudos sobre sua utilização como forrageira em regiões montanhosas.

Os consórcios com estilosantes mostraram-se promissores, com altas produções de MS nas duas colheitas (agosto e dezembro/99) e elevados teores de PB e de Ca, além de moderados teores de FDN, aumentando a disponibilidade e a qualidade da forragem na pastagem. 


\section{Literatura Citada}

ALVIM, M.J.; BOTREL, M.A.; VERNEQUE, R.S. et al. Aplicação de nitrogênio em acessos de Brachiaria. 1. Efeitos sobre produção de matéria seca. Pasturas Tropicales, v.12, n.2, p.2-6, 1990.

ANDRADE, I.F. Produção e composição química de leguminosas forrageiras cultivadas no cerrado de Sete Lagoas. Revista da Sociedade Brasileira de Zootecnia, v.11, n.2, p.341-359, 1982

BODDEY, R.M.; RESENDE, C.P.; SCHUNKE, R.M. et al. Sustentabilidade de pastagens consorciadas e de gramínea em monocultura. In: REUNIÃO ANUAL DA SOCIEDADE BRASILEIRA DE ZOOTECNIA, 30., 1993, Rio de Janeiro. Palestras dos Simpósios... Niterói: Sociedade Brasileira de Zootecnia, p.141-173. 1993.

BOGDAN, A.V. Tropical pasture and fodder plants. Tropical Agricultures Series. Longman, 1977. p.167-170.

BOTREL, M.A.; ALVIM, M.J.; XAVIER, D.F. et al. Avaliação de forrageiras em dois municípios do Campo das Vertentes de Minas Gerais. Revista da Sociedade Brasileira de Zootecnia, v.23, n.2, p.189-196, 1994.

BROCKINGTON, N.R.; ZOCCAL, R.; VEIL, J. M. et al. O uso da simulação nos estudos de pastagens. 3. Introdução de capim-braquiária (Brachiaria decumbens, Stapf.) em pastagens degradadas de capim-gordura (Melinis minutiflora, Beauv.). In: REUNIÃO ANUAL DA SOCIEDADE BRASILEIRA DE ZOOTECNIA, 23., 1986, Campo Grande. Anais... Campo Grande: Sociedade Brasileira de Zootecnia, 1986. p.353.

CANTARUTTI, R.B.; BODDEY, R.M. Transferência de nitrogênio das leguminosas para as gramíneas. In: SIMPÓSIO INTERNACIONAL SOBRE PRODUÇÃO ANIMAL EM PASTEJO, 1., 1997, Viçosa, MG. Anais... Viçosa, MG: Universidade Federal de Viçosa, 1997. p.431-445.

CARVALHO, M.M.; CRUZ FILHO, A.B. Desenvolvimento de pastagens em áreas de relevo acidentado. In: CARVALHO, M.M., ALVIM, M.J. (Eds.). Pastagens para gado de leite em regiões de influência da Mata Atlântica. Juiz de fora, MG: Embrapa Gado de Leite, 2000. p.53-81.

CARVALHO, M.M.; SARAIVA, O.F. Resposta do capimgordura (Melinis minutiflora, Beauv.) a aplicações de nitrogênio, em regime de cortes. Revista da Sociedade Brasileira de Zootecnia, v.16, n.5, p.442-454, 1987.

CÓSER, A.C.; CRUZ FILHO, A.B. Estabelecimento de leguminosas em pastagens de capim-gordura. Revista da Sociedade Brasileira de Zootecnia, v.18, n.5, p.410-416, 1989.

CRUZ FILHO, A.B.; CÓSER, A.C.; NOVELLY, P.E. Comparação entre métodos de plantio de Brachiaria decumbens em pastagens de capim-gordura em áreas montanhosas. Revista da Sociedade Brasileira de Zootecnia, v.15, n.4, p.297-306, 1986

DÖBEREINER, J. Biological nitrogen fixation in the tropics: Social end economic contributions. Soil Biology and Biochemistry, v.29, p.771-774, 1997.

EUCLIDES, R.F. Sistema de análise estatística e genética. Viçosa, MG: Unviersidade Federal de Viçosa, 2003.68p.

FERNANDES, F.M.; ISEPON, O.J.; NASCIMENTO,V.M. Resposta de Brachiaria decumbens a níveis de NPK em solo originalmente coberto por vegetação de cerrado. Científica, v.13, p.89-97, 1985.

FONSECA, D.M.; GOMIDE, J.A.; ALVAREZ V., V.H. et al.
Absorção, utilização e níveis críticos de fósforo em Andropogon gayanus, Brachiaria decumbens e Hyparrhenia rufa. Revista da Sociedade Brasileira de Zootecnia, v.21, n.4, p.731-743, 1992.

GARDNER, A.L. Técnicas de pesquisa em pastagens e aplicabilidade de resultados em sistemas de produção. Brasília: IICA; EMBRAPA CNPGL, 1986. 197p.

GOMIDE, J.A.; COSTA, G.G.; SILVA, M.A.M.M. Adubação nitrogenada e consorciação do capim-colonião e capim-jaraguá. 2. Composição mineral e digestibilidade da matéria seca dos componentes da mistura. Revista da Sociedade Brasileira de Zootecnia, v.13, n.1, p.22-29, 1984c.

GOMIDE, J.A.; LEÃO, M.I.; OBEID, J.A. et al. Avaliação de pastagens de capim-colonião (Panicum maximum Jacques) e capim-jaraguá (Hyparrhenia rufa (Ness) Stapf). Revista da Sociedade Brasileira de Zootecnia, v.13, n.1, p.1-9, 1984a.

GOMIDE, J.A.; COSTA, G.G.; SILVA, M.A.M.M. et al. Adubação nitrogenada e consorciação do capim-colonião e capimjaraguá com leguminosas. 1. Produtividade e teor de nitrogênio das gramíneas e das misturas. Revista da Sociedade Brasileira de Zootecnia, v.13, n.1, p.11-21, 1984b.

GOMIDE, J.A.; OBEID, J.A.; OLIVEIRA, J.M. Introdução de leguminosas tropicais em pastagens de gramíneas. Revista da Sociedade Brasileira de Zootecnia, v. 8, n.4 p.593-609, 1979.

KÖEPEN, W. Climatologia. Buenos Aires: Gráfica Panamericana, 1948. 478p.

LOMBARDI NETO, F. Degradação das pastagens. In: ENCONTRO SOBRE RECUPERAÇÃO DE PASTAGENS, 1993, Nova Odessa. Anais... Nova Odessa: Instituto de Zootecnia, 1993. p.49-59.

MANNETJE, L.T.; HAYDOCK, K.P. The dry-weight-rank method for the botanical analysis of pasture Journal British. Grassland Society, v.18, n.4, p.268-275, 1963.

MARSCHNER, H. Mineral nutrition of higher plants. 2.ed. New York: Academic Press, 1995. 874p.

MEIRELLES, N.M.F. Degradação de pastagens - Critérios de avaliação. In: ENCONTRO SOBRE RECUPERAÇÃO DE PASTAGENS, 1993, Nova Odessa. Anais... Nova Odessa: Instituto de Zootecnia, 1993. p.1-27.

MILFORD, R.; MINSON, D.J. Intake of tropical pasture species. In: CONGRESSO INTERNACIONAL DE PASTAGENS, 9. 1965, São Paulo. Anais... São Paulo: Alarico, 1966. p.815-822.

NASCIMENTO JR., D. Aspectos gerais da avaliação de pastagens. Seminário de avaliação de pastagens. In: SEMINÁRIO DE AVALIAÇÃO DE PASTAGENS, 1991, João Pessoa. Anais... João Pessoa: Sociedade Brasileira de Zootecnia, 1991. p.1-37.

NEPTUNE, A.M.L. Aplicação de calcário em culturas forrageiras. In: PEIXOTO, A.M., MOURA, J.C., FARIA, V.P. (Eds.). Pastagens: fundamentos da exploração racional. Piracicaba: Fundação de Estudos Agrários Luiz de Queiroz, 1986. p.73-107.

PUPO. N.I.H. Manual de pastagens e forrageiras: formação, conservação, utilização. Campinas: Instituto Campineiro de Ensino Agrícola, 1979. 343p.

RIBEIRO, K.G.; GOMIDE, J.A.; PACIULLO, D.S.C. Adubação nitrogenada do capim-elefante cv. Mott. 2. Valor nutritivo ao atingir 80 e $120 \mathrm{~cm}$ de altura. Revista da Sociedade Brasileira de Zootecnia, v.28, n.6, p.1194-1202, 1999.

SILVA, D.J; QUEIROZ, A.C. Análise de alimentos (métodos químicos e biológicos). 3.ed. Viçosa, MG: Universidade Federal de Viçosa, 2002. 235p. 
SILVA, M.A.M.M. Adubação nitrogenada e consorciação do capim-jaraguá (Hyparrhenia rufa (Nees) Stapf) com soja perene (Neonotonia wightii (Wight at Arn) Lackey) e centrosema (Centrosema pubescens Benth). Viçosa, MG: Universidade Federal de Viçosa, 1983. 35p. Dissertação (Mestrado em Zootecnia) - Universidade Federal de Viçosa, 1983.

SOARES FILHO, C.V. Recomendação de espécies e variedades de Brachiaria para diferentes condições. In: SIMPÓSIO SOBRE MANEJO DA PASTAGEM, 11., 1994, Piracicaba. Anais... Piracicaba: Fundação de Estudos Agrários Luiz de Queiroz, 1994.p.25-48.

Van SOEST, P.J. Symposium on factors influencing the voluntary intake of herbage by ruminants: voluntary intake relation to chemical composition and digestibility. Journal of Animal Science, v.24, n.3, p.834-44, 1965.
WENDLING, I.J. Produção de leite em pastagem de capimbraquiária (Brachiaria decumbens) sob duas ofertas diárias de forragem. Viçosa, MG: Universidade Federal deViçosa, 1997. 47p. Dissertação (Mestrado em Zootecnia) - Universidade Federal de Viçosa, 1997.

Recebido em: 12/09/03

Aceito em: 21/10/04 